\title{
An Exploratory Factor Analysis of Older Adults' Resistance to Innovation Adoption: A Case Study of University of Botswana
}

\author{
Alexander Ngozi Ifezue \\ Department of Marketing, Faculty of Business, University of Botswana, Gaborone \\ E-mail: ifezue@mopipi.ub.bw
}

\begin{abstract}
Njoku Ola Ama
Department of Statistics, Faculty of Social Sciences, University of Botswana, Gaborone E-mail: amano@mopipi.ub.bw; njoku52@gmail.com
\end{abstract}

K. K. Moseki

Department of Statistics, Faculty of Social Sciences, University of Botswana, Gaborone E-mail:mosekikk@mopipi.ub.bw

Received: July 24, 2016

doi:10.5296/jmr.v8i4.9825
Accepted: Sep 12, 2016 Published: October 1, 2016

URL: http://dx.doi.org/10.5296/jmr.v8i4.9825

\begin{abstract}
This paper analysed the resistance to innovation of a stratified sample of 279 staff members of the University of Botswana with the view to determine those factors that act as roadblocks, institutional barriers and boosters to innovation use in the university. Using an exploratory factor analysis (EFA) and multivariate binary logistic regression techniques, lack of innovation, perceived risks and institutional environment were identified as roadblocks/barriers to innovation use by the older adults (50 years and over). Access to computer and years of internet experience significantly, positively affected innovation use ( $p$ $<0.05, \mathrm{~B}>0$ ). Training and motivation were also identified as factors that act as boosters to innovation use. The paper recommends for the designing of intensive training programme for
\end{abstract}


the older adults that is age-specific and which takes into consideration the existing skills in order to motivate them to use the innovations.

Keywords: Innovation, resistance, older adults, exploratory factor analysis 


\section{Introduction}

Ram and Sheth (1989) defined innovation resistance as the resistance offered by consumers to innovation, either because it poses potential changes from a satisfactory status quo or because it conflicts with their belief structure. The consumer resistance attitude exhibited by an individual can either inhibit or delay adoption of an innovation. Two factors that have been considered important to help in a consumer's decision to adopt an innovation ( see Dunphy and Herbig, 1995; Hosseini et al., 2016) are (i) the consumers' characteristics entrenched in the psychological characteristics of consumers and how the consumers perceive innovativeness with respect to the particular product, and (ii) the innovation characteristics which is measured in terms of the outcome and effects of innovation on the consumers. Ram andSheth (1989) categorized barriers that cause innovation resistance among consumers as functional and psychological barriers which are related to how the products are used, value of the products and the risks associated with using the products. The psychological barriers emanate from the traditions and norms of the consumers, and perceived product image. Functional barriers arise if consumers perceive significant changes in their daily routines as a result of adopting the innovation. Other studies, for example, Mattila et al. (2003), have indicated that mature consumers are late adopters of new electronic services. Härkönen(2004) recommended and emphasized the need to study the reasons why mature customers are late adopters of new electronic services.

A number of authors e.g. Ram (1986), Ram and Sheth (1989), Sheth (1981) and Hosseini et al. (2016) have shown that consumer resistance can be instrumental to the market failure of innovations and can constitute an important source of information to the successful implementation and marketing of innovation ( see also, Connor et al., 1998). Ram (1987) is of the opinion that emphasis on innovation use should shift from the adoption and diffusion perspectives and rather focus more on the study of the process of innovation resistance, even though, in his model of innovation resistance, Ram (1987) argued that resistance and adoption can still coexist during the life of an innovation. It is, therefore, of utmost importance that innovation resistance should be studied. Firms need to understand consumer resistance in the light of why consumers resist innovation and the influencing factors to innovativeness, as this will help to improve their innovative efforts, and identify ways to improve competitiveness, productivity, and profitability (Dunphy and Herbig, 1995).

An understanding of the decision process of consumers to adopt and purchase an innovation can make a lot of significant difference in the successful implementation of the innovation. It is, therefore, of utmost importance to study consumers' resistance as an important factor in the innovation process. It can, certainly, inhibit and/or delay the diffusion of an innovation and has been shown to have very important implications for the management of firms (Bradley \& Stewart, 2002). Laukkanen et al. (2008) and Khan and Hyunwoo, (2009) noted that most of the consumers, who resist innovation, are non-adopters and they constitute a major part of consumers of any innovation. They do not need to be overlooked in the research studies as they can provide valuable information necessary for the development, implementation, and marketing of innovation. Khan and Hyunwoo (2009) noted that, despite the importance of innovation resistance, not many studies have been done in this area and 
recommended that further research on innovation resistance from individual and or organizational perspectives be carried out.

But why should a non-profit-seeking institution such University of Botswana (UB) want to know whether or not their innovation technologies are being resisted by staff members? The university is composed of two types of staff, the older adults (50 years and over) and those less than 50 years of age. The older adults (50years and over) represent a good proportion of staff in the university. Literature on innovation use and adoption (e.g. Mattila et al., 2003) show that a significant difference in the innovation usage by this group and younger age groups exists. Often the interests of the older adults, who probably had finished schooling before the advent of computers, are not taken on-board when new innovations are introduced in the institution, yet everyone is expected to adopt and use the innovations at the same rate. Even when trainings are provided to acquaint staff with the innovations, the trainings do not take into consideration the differences in the skills in use computers among the two age groups. Oftentimes, there is an inherent resistance to institutional innovations which could be a function of age. Lundsford and Burnett (1992) studied technology adoption among mature consumers. They found five barriers - product usage, values, self-image, enduring cultural values and risks, which have to be overcome before mature consumers adopt new technology. Furthermore, innovations are imposed on staff members of the institution and no effort has been made to determine the following: how easy staff members find it to use the innovations; the degree of change and disruption of their established routines brought about by the innovation in their day-to-day existence; the extent to which the innovations conflict with the staff-members' prior belief structure; and whether these innovations have the characteristics that impede or facilitate a quick diffusion and render them to be well-accepted by the staff-members. In the real world situation, the consumer can accept or reject innovations by buying or not buying it, but the uniqueness of the environment of University of Botswana staff does not give them the right to reject undesirable new innovation. How to resolve this issue requires a delicate balance and is still largely unknown.

The University of Botswana has staff strength of 2678 which include: Academic, Support and Industrial Staff. The institution has a number of innovation technologies that have been put in place to facilitate the working systems. They include the following: Blackboard (management of online teaching), ASAS (Academic and Student Administration System), I-ERP (on-line financial management system), Moodle (a software package for producing internet-based courses and websites), and Research Management System (RMS). It is mandatory for academic staff to use, on daily basis, the Blackboard, Moodle, ASAS, I-ERP and Research Management System to upload research outputs and apply for research funding, notes and assignment for students and enter results of examinations and tests. The support staff use, mainly, the I-ERP, Moodle (for those that are running some academic programmes). The staff resistance to the effective use of these innovations have never been investigated empirically and constitute the crux of this paper.

The purpose of this study are to: explore how resistant to innovations the older adults and those less than 50 years at the University of Botswana are; determine the attitudes of staff to new innovations; identify the most common roadblocks to the innovation adoption; find out 
the institutional barriers to implementing innovations at the University; determine the factors staff members believe would facilitate adoption of innovations; and come up with recommendations on how to improve innovation implementation. In the literature, no one has looked at innovation resistance from the perspective of institutions of higher learning. Therefore, the study is both appropriate and timely and will help institutions and other corporate bodies improve their staff training programmes on the use of the technologies.

\section{Literature Review}

Not many studies have been done on the issue of older adults' consumer behaviours and resistance to innovation. However, a related study by Reisenwitz et al. (2007) cited in Lian and Yen (2014) found that the elderly in America (over age 65) who are nostalgichardly use the Internet or shop online, and also, they get less enjoyment out of it. The study further indicated that personal innovativeness will affect online behaviours such as use frequency, online shopping adoption, and use for pleasure. Another study by Kwon and Noh (2010) on the online clothes-shopping behaviour of older American consumers found that consumer's perceptions of the benefits of the product, how much discount they could get on purchase of the products, and the financial risk were determinants of their intention to shop for clothing online. In addition, the study found out that previous online shopping experiences affected the older consumers' perceptions of financial risk and benefits of shopping online. However, age and online experience did not strongly affect online shopping intentions.

McCloskey (2006) studied older Americans' attitudes toward participating in e-commerce activities and found that website usefulness and user trust (regarding the website) positively affects user behaviour and ease of use and trust also affects users' perceptions of usefulness. Ryu, Kim, and Lee (2009), in their study to understand the critical factors affecting the willingness of adults over 50 to participate in the Video User-Created Content (Video UCC), found that perceived benefits, ease of participation and enjoyment directly affect participants' behaviours. The other critical factors to older adults' participations identified included how they perceive their health condition, life course events, available resources, previous related experiences and computer anxiety.

Pfeil, Arjan, and Zaphiris (2009) compared the online social community behaviours between younger (13-19 years old) and older (over 60) users and found out that the younger users have more friends online than the older users and most of whom are their peers. Moles worth and Suortti (2002) found that users between the ages of 20 and 57 are prevented from buying high-involvement and high-cost products online because of such barriers as usability, risk, tradition and image. Similarly, Laukkanen et al. (2007) compared the perceptions of usersof mobile banking from different age groups and found that users who are younger than 55 years old regard usage and value to be the barriers while users older than 55 years of age deem usage, value, risk, tradition, and image as barriers. Laukkanen et al. (2008) in their study of the adoption of Internet banking by individuals aged 18-65 further classified the non-adopters of Internet banking into three groups: postponers (postponement occurs when consumers delay the adoption of an innovation), opponents (protesting the innovation or searching for further information after the trial)and rejecters (see also Kuisma et al., 2007). 
The study found that postponers have no significant barriers causing them to resist innovations. Opponents find risk, tradition, and image to be barriers to the adoption of Internet banking while rejecters have higher barriers than others, with risk and tradition being the most critical.

Thomas (1971) characterized Innovation Resistance on the basis of the timing of adoption of innovation as: Innovators, Early Adopters, Early Majority, Late Majority, and Laggards (see also, Rogers, 2003). Each of these groups has different levels of resistance to the innovation which affects the timing of adoption. The paper shows that innovators do not exhibit resistance to the innovation and are usually the first to adopt. The laggards have such a high level of resistance that they do not adopt the product at all. The early adopters, early majority and late majority exercise resistance to the innovation in different degrees. For instance, the early adopters have passive resistance (feel disinclined to adopt the innovation) while the early majority exercise active resistance (feel that the innovation is too risky and postpone the adoption decision) and the late majority have a very active resistance (convinced that the innovation is unsuitable and decide to launch an attack against its adoption)(Ram, 1985; Thomas, 1971).

\section{Methodology}

Coverage: The study covered all staff at the University of Botswana. Data available from the Institutional Planning shows that as at 2013/2014 there were 902 academic staff, 1425 support staff and 351 industrial staff at the University of Botswana.

Sample size: The Creative Research Systems (2012) shows that a statistically appropriate sample size for this study for a population of 2678 staff is 384 at $95 \%$ confidence level and $5 \%$ confidence interval (margin of error).

Sampling Design and Sample size allocation: The study used the stratified random sampling method where the academic cadre, support staff cadre and industrial class cadre constituted the strata. The sample size of 384 was proportionately allocated to the 3 strata and the simple random sampling was then used in identifying staff to be studied in each stratum.

Table 1. Proportional allocation of sample size

\begin{tabular}{|l|c|c|c|}
\hline Staff Category & Population & Sample size & Achieved sample size \\
\hline Academic & 902 & 130 & 179 \\
Support Staff & 1425 & 204 & 69 \\
Industrial Staff & 351 & 50 & 31 \\
\hline Total & 2678 & 384 & 279 \\
\hline
\end{tabular}

Source: Institutional Planning, University of Botswana

Data Collection: Questionnaires were self-administered to the selected staff by trained research assistants working with the researchers. The researchers explained the purpose of the 
study to staff members and obtained their consent. The self-administration of the questionnaire was because staff members could not find time to sit with the research assistants/researchers for a face-to-face interview, while at work. At the end of data collection, 279 completed questionnaires were retrieved (Table 1) giving a response rate of 72.7\%. This response rate is very much higher than that obtained by Sevick and Bradham (1997) (19.7\%) and Härkönen (2004) (50\%) in similar studies. Visser et al. (1996) demonstrated that surveys with low response rates are not necessarily low in validity. Table 1 shows that the academic were oversampled. This was to make up the drop in the responses of the support and the industrial staff who were less responsive in answering the questions.

Ethical Issues: The study was approved by University of Botswana Institutional Review Board (IRB).

\section{Results}

Table2 shows the socio-demographic characteristics of the staff of the University of Botswana who participated in the study. The table reveals that $194(69.5 \%)$ of the respondents were below age 50 years while 85 (30.5\%) respondents were 50 years and over (older adults). Of the respondents below 50 years, $53.1 \%$ were males and $46.9 \%$ were females. The older adults were made up of $68.2 \%$ males and $31.8 \%$ females. While $79.3 \%$ of the respondents below 50 years have degree or higher qualifications, the corresponding percentage for respondents 50 years and over was $90.5 \%$. More than half $(52.9 \%)$ of the respondents 50 years and over earned P33, 000.00 and over per month, while the corresponding percentage monthly earning for staff below 50 years was $12.9 \%$. Majority of the respondents $(51.5 \%$ aged less than 50 and $76.5 \%$ aged 50 years and over) were married. The single (never married) were $44.8 \%$ of those less than 50 years and $11.8 \%$ of the older adults. The percentage of the staff that had computers in their home or office was $91.2 \%$ of those less than 50 years and $96.5 \%$ of the older adults. Majority of the respondents were academic staff (56.2\% of those below 50 and $82.4 \%$ of the older adults). 
Table 2. Socio-demographic characteristics of the respondents

Characteristics of the respondents

Age of respondent

\begin{tabular}{|c|c|c|c|c|c|}
\hline & & & \\
\hline & & Number & $\%$ & Number & $\%$ \\
\hline \multirow{2}{*}{ Sex of respondent } & Male & 103 & 53.1 & 58 & 68.2 \\
\hline & Female & 91 & 46.9 & 27 & 31.8 \\
\hline \multirow[t]{8}{*}{ Highest educational qualification } & Secondary & 4 & 2.1 & 2 & 2.4 \\
\hline & Diploma & 36 & 18.6 & 6 & 7.1 \\
\hline & Degree & 70 & 36.1 & 43 & 50.6 \\
\hline & Professional & 22 & 11.3 & 3 & 3.5 \\
\hline & Ph.D. & 13 & 6.7 & 19 & 22.4 \\
\hline & Master's degree & 48 & 24.7 & 12 & 14.1 \\
\hline & AAT(Association of Accounting & & & & \\
\hline & Technicians) & 1 & 0.5 & 0 & 0 \\
\hline \multirow{8}{*}{ Monthly income } & Below 3000.00 & 10 & 5.2 & 1 & 1.2 \\
\hline & $3000-7999.00$ & 13 & 6.7 & 0 & 0 \\
\hline & $8000-12999.00$ & 24 & 12.4 & 3 & 3.5 \\
\hline & $13000-17999.00$ & 30 & 15.5 & 3 & 3.5 \\
\hline & $18000-22999.00$ & 44 & 22.7 & 4 & 4.7 \\
\hline & $23000-27999.00$ & 28 & 14.4 & 9 & 10.6 \\
\hline & 28000-32999.00 & 20 & 10.3 & 20 & 23.5 \\
\hline & 33000 and above & 25 & 12.9 & 45 & 52.9 \\
\hline \multirow[b]{6}{*}{ Marital Status } & Single & 87 & 44.8 & 10 & 11.8 \\
\hline & Married & 100 & 51.5 & 65 & 76.5 \\
\hline & Cohabiting & 2 & 1 & 1 & 1.2 \\
\hline & Divorced & 3 & 1.5 & 5 & 5.9 \\
\hline & Separated & 1 & 0.5 & 0 & 0 \\
\hline & Widowed & 1 & 0.5 & 4 & 4.7 \\
\hline \multirow{2}{*}{$\begin{array}{l}\text { You have a computer at your } \\
\text { home/office }\end{array}$} & Yes & 177 & 91.2 & 82 & 96.5 \\
\hline & No & 17 & 8.8 & 3 & 3.5 \\
\hline \multirow{3}{*}{$\begin{array}{l}\text { Your computer has internet } \\
\text { connected }\end{array}$} & Yes & 158 & 81.4 & 79 & 92.9 \\
\hline & No & 29 & 14.9 & 3 & 3.5 \\
\hline & Not stated & 7 & 3.6 & 3 & 3.5 \\
\hline \multirow[t]{2}{*}{ Your job classification } & Academic staff & 109 & 56.2 & 70 & 82.4 \\
\hline & Administrative and Support staff & 85 & 43.8 & 15 & 17.6 \\
\hline
\end{tabular}




\section{Characteristics of innovation resistance}

Innovation resistance can be characterized by the timing of the adoption of innovation as: Innovators, Early Adopters, Early Majority, Late Majority, and Laggards. The respondents were asked to classify themselves in terms of their innovation adoption. The results of the responses are summarized in Figure 1. The figure shows that the older adults are more of the early majority (36.1\%), late majority $(16.9 \%)$ and laggards $(1.2 \%)$ while those less than 50 years of age are more of innovators $(25.7 \%)$ and early adopters $(44.4 \%)$. When the respondents are further classified into resistant (early adopters, early majority, late majority and laggards) and non-resistant (innovators), the results reveal that older adults are more resistant to innovation $(85.5 \%)$ than the younger ones $(75.3 \%)$.

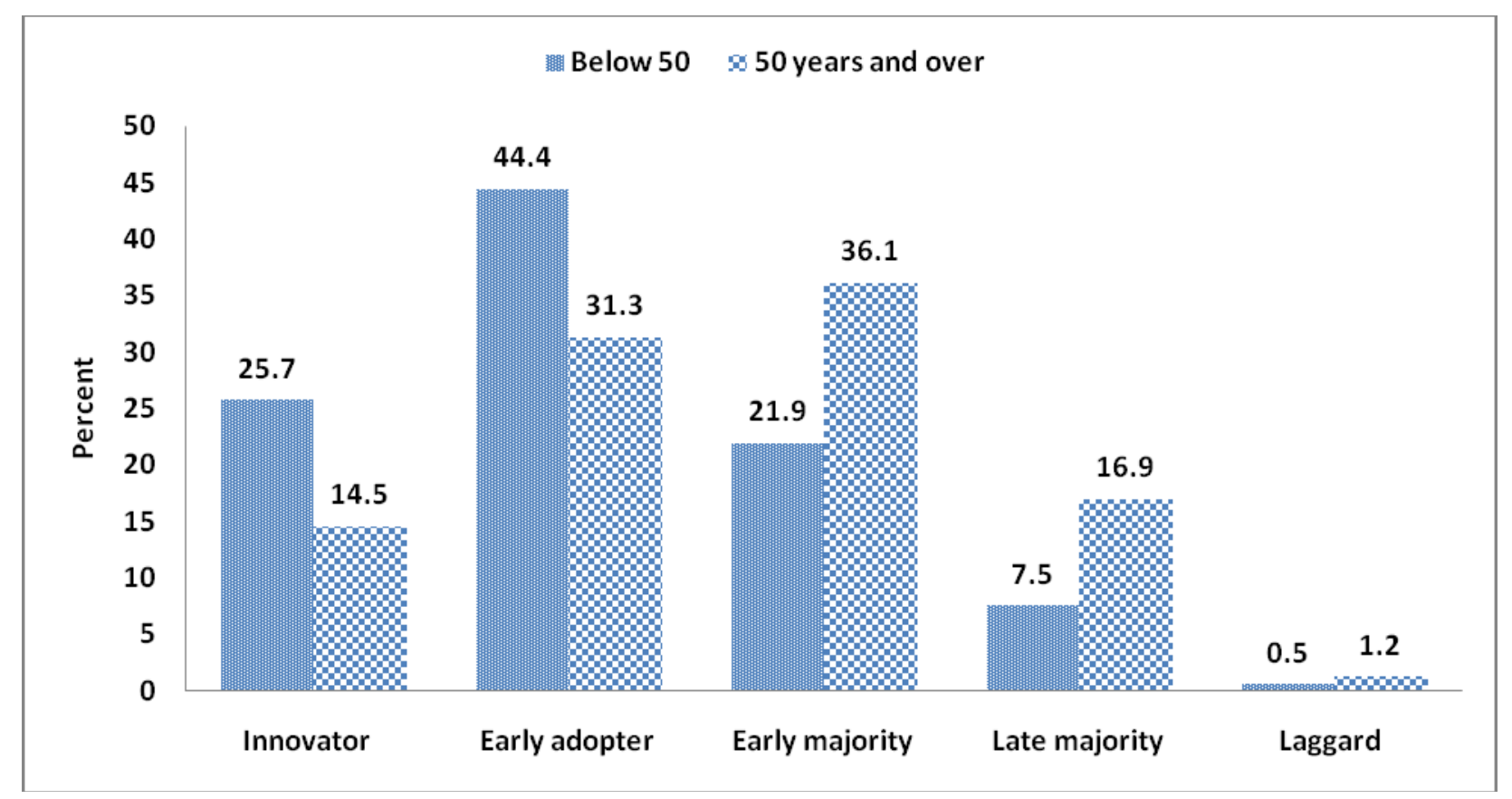

Figure 1. University of Botswana Staff response towards innovation resistance

\section{Usage of innovation technologies at the University of Botswana}

The respondents were asked to indicate how comfortable or uncomfortable they are in using some of the innovations that have been introduced at the University of Botswana to facilitate the daily performance of the assignments of academic and support staff. These innovations include Blackboard (for management of online teaching), ASAS (Academic and Student Administration System), I-ERP (on-line financial management system), Moodle (a software package for producing internet-based courses and websites) and the Research Management System (for management of research outputs and research proposals). Table 3 summarized the responses of the participants. The percentage of older adults who are comfortable using the Blackboard (81\%), ASAS (89\%) and Research Management System (53.8\%) are greater than those aged less than 50 years $(77.8 \%, 86.6 \%$ and $44 \%$, respectively). However, a little more of the respondents aged less than 50 years are more comfortable using Moodle $(53 \% ; 41.5 \%)$ and I-ERP (79.9\%; 74.7\%) than the older adults (Table 2). 
Table 3. Level of comfort in usage of technologies at University of Botswana

\begin{tabular}{ll|cc|cr}
\hline \multirow{2}{*}{ Use of available technology at University of Botswana } & \multicolumn{4}{|c}{ Age of respondent } \\
\cline { 3 - 6 } & & \multicolumn{3}{|c}{ Below 50 } & 50 years and over \\
\cline { 3 - 6 } & Cumber & $\%$ & Number & $\%$ \\
\hline \multirow{2}{*}{ Blackboard (management of online teaching) } & Uncomfortable & 112 & 77.8 & 51 & 81 \\
& Comfortable & 142 & 86.6 & 65 & 89 \\
\hline ASAS (Academic and Student Administration & Uncomfortable & 22 & 13.4 & 8 & 11 \\
\hline System) & Comfortable & 135 & 79.9 & 56 & 74.7 \\
\hline \multirow{2}{*}{ I-ERP (on-line financial management system) } & Uncomfortable & 34 & 20.1 & 19 & 25.3 \\
\hline Moodle (a software package for producing & Comfortable & 71 & 53 & 22 & 41.5 \\
internet-based courses and websites). & Uncomfortable & 63 & 47 & 31 & 58.5 \\
\hline Research Management System (for & Comfortable & 55 & 44 & 28 & 53.8 \\
management of research output and proposals) & & & & & \\
& Uncomfortable & 70 & 56 & 24 & 46.2 \\
\hline
\end{tabular}

In order to determine the factors that influence use of innovation technologies by the staff of the university, a multivariate binary logistic regression model was fitted to some socio-economic (access to computer and monthly income) and demographic variables (highest educational qualification, age and years of internet experience). The dependent variable was the log of the odds of using innovation. The results are shown in Table 4.

The results (Table 4) show that access to computer at home/office and years of internet experience are positively significant predictors of the use of innovation technology $(p<0.05)$ whereaseducation, monthly income and age are not significant predictors of usage. Furthermore, respondents who have access to computer at home/office are about 4 times more likely to use the innovation technology than those who do not have any. Higher educational qualification increases the likelihood of using the innovation. For instance, while those who have degrees are 1.85 times more likely to use the innovation than those with diploma certificate or lower, those who have other professional qualifications are 5 times more likely to use the innovation. Having higher income is negatively correlated with usage of innovation technology ( $<<0$ ). Those who earn between P13, 000 and P27, 999.00 as likely to use as those earning below P13, 000.00 while those who earn P28, 000.00 and over are less likely to use the innovation than those who earn below P13, 000.00. The older one is, the more the likelihood of using innovation technologies in the university. For instance, respondents who are aged 40-59 and 60-79 years are, respectively, 1.7 and 3.35 times more likely to use the innovations than those aged 20-39. Similarly, respondents who have 10-24 and 25 or more years of internet experience are, respectively, 1.7 and 5.56 times more likely to use the innovations than those with less than 10 years of experience. 


\section{Macrothink}

Journal of Management Research

ISSN 1941-899X

2016, Vol. 8, No. 4

Table 4. Logistic regression model to predict factors that affect use of innovation

\begin{tabular}{|c|c|c|c|c|c|c|c|}
\hline \multirow{2}{*}{\multicolumn{2}{|c|}{$\begin{array}{l}\text { Reference Category Variables in the } \\
\text { Equation }\end{array}$}} & \multirow{3}{*}{$\begin{array}{c}\mathrm{B} \\
1.383\end{array}$} & \multirow{3}{*}{$\begin{array}{ll}\text { S.E. } \\
0.61\end{array}$} & \multirow{3}{*}{$\begin{array}{l}\text { Wald } \\
5.145 \\
\end{array}$} & \multirow[b]{2}{*}{$\mathrm{df}$} & \multirow[b]{2}{*}{ Sig. } & \multirow[b]{2}{*}{$\operatorname{Exp}(\mathrm{B}) / \mathrm{OR})$} \\
\hline & & & & & & & \\
\hline No & Access to computer & & & & 1 & 0.023 & 3.986 \\
\hline \multirow{3}{*}{$\begin{array}{l}\text { Diploma } \\
\text { certificate and } \\
\text { below }\end{array}$} & $\begin{array}{l}\text { Highest educational } \\
\text { qualification }\end{array}$ & & & 4.553 & 2 & 0.103 & \\
\hline & Degree & 0.614 & 0.654 & 0.882 & 1 & 0.348 & 1.848 \\
\hline & Others & 1.614 & 0.822 & 3.854 & 1 & 0.05 & 5.023 \\
\hline \multirow{3}{*}{ Below 13,000} & Monthly income & & & 3.16 & 2 & 0.206 & \\
\hline & $13,000-27999$ & 0.017 & 0.583 & 0.001 & 1 & 0.977 & 1.017 \\
\hline & 28000 and over & -0.808 & 0.716 & 1.274 & 1 & 0.259 & 0.446 \\
\hline \multirow[t]{3}{*}{$20-39$} & Age of respondent & & & 1.736 & 2 & 0.42 & \\
\hline & $40-59$ & 0.528 & 0.452 & 1.366 & 1 & 0.243 & 1.696 \\
\hline & $60-79$ & 1.21 & 1.238 & 0.956 & 1 & 0.328 & 3.354 \\
\hline \multirow[t]{4}{*}{ Below 10} & Years of internet experience & & & 8.99 & 2 & 0.011 & \\
\hline & $10-24$ & 0.533 & 0.788 & 0.457 & 1 & 0.499 & 1.703 \\
\hline & 25 and over & 1.715 & 0.832 & 4.253 & 1 & 0.039 & 5.558 \\
\hline & Constant & -3.454 & 0.945 & 13.367 & 1 & 0 & 0.032 \\
\hline
\end{tabular}

\section{Attitude to new innovations}

Consumer resistance can lead consumers to respond in three different ways: direct rejection, postponement or opposition to innovation technology (Mirella et al., 2009). The respondents were asked, "What has been your attitude towards this new innovation?" Figure 2 shows how the participants respond to innovation technology. The figure reveals that when confronted with a new innovation, $76 \%$ of staff less than 50 years and $73 \%$ of older adults would want to postpone adoption of the new technology, while $15 \%$ of those less than 50 years and $19 \%$ of older adults would oppose its use. The percentages that would opt for outright rejection of the new technology are $9 \%$ of those less than 50 years and $8 \%$ of the older adults. 


\section{Macrothink}

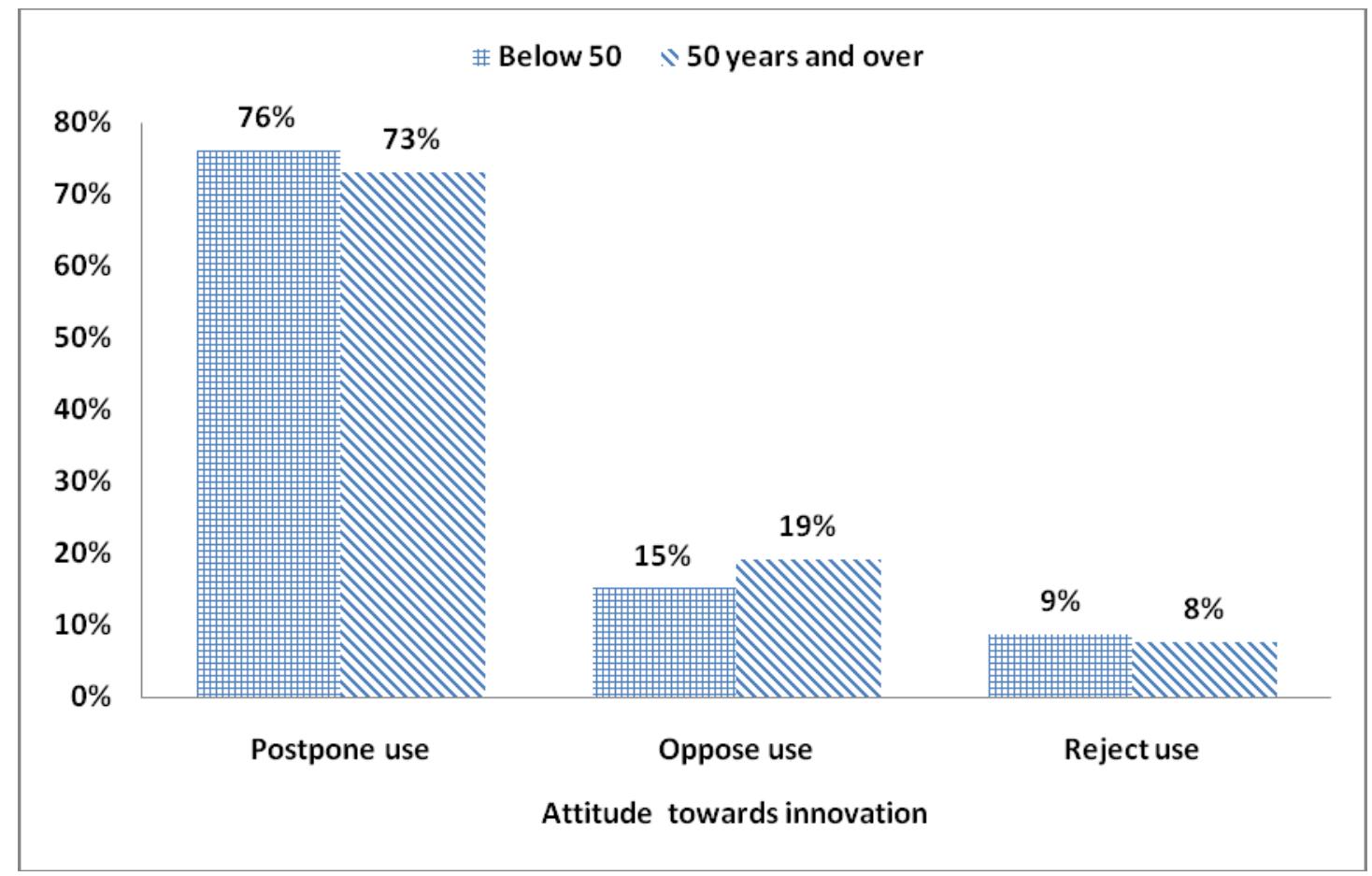

Figure 2. Participants' attitude to new innovations

\section{Roadblocks to innovation adoption among university staff}

In order to explore the roadblocks to innovation adoption among University of Botswana staff, the respondents were asked to rate some factors according to how they negatively affect their ability/desire to adopt an innovation using the scale: 1=Very unimportant; 2=Unimportant; $3=$ Neutral; 4=Important; $5=$ Very important. The responses were subjected to exploratory factor analysis (EFA) using the principal component analysis and Varimax with Kaiser Normalization procedure. The results of the EFA for respondents less than 50 years and those 50 years and over (older adults) are shown separately in Table 5. In the analysis, only factors with associated variance (Eigen values) greater than 1 are retained and also only factor loadings $>0.5$ are shown.

The Kaiser-Meyer-Olkin(KMO) Measure of Sampling Adequacy $(\alpha)$ and the Bartlett's Test of Sphericitywere carried out to test the adequacy of the sample for factor analysis and the hypothesis that the variables are uncorrelated in the population. In other words, if the population correlation matrix is an identity matrix, each variable correlates perfectly with itself $(\mathrm{r}=1)$ but has no correlation with the other variables $(\mathrm{r}=0)$. For deciding on the value of $\alpha$, George and Mallery (2003, p. 231) provide the following rules of thumb: " $\alpha>0.9$ - Excellent, $\alpha>0.8$ - Good, $\alpha>0.7$ - Acceptable, $\alpha>0.6$ - Questionable, $\alpha>0.5$ - Poor, and $\alpha<0.5$ Unacceptable" indicating that factor analysis may not be appropriate. In other words,small values of the KMO statistic indicate that the correlations between pairs of variables cannot be explained by other variables and that factor analysis may not be appropriate. The value of alpha 
partially depends upon the number of items (variables/questions) in the scale. It is to be noted that the more the number of variables/questions, the less will be the consistency.

For the respondents below 50 years of age, three factors, lack of motivation, complexity and perceived risks in the adoption of the innovation were extracted. The factor lack of motivation explained $58.6 \%$ of the total variation and is heavily loaded on the variables: No executive sponsorship (0.856), Inadequate funding (0.773), Contracting issues between university and supplier (0.764), Stiff legal requirements in using the innovation (0.757), No time for innovation (time consuming) (0.741), Risk of affecting my cultural way of life (0.738), No business case for product (669) and No performance criterion (0.617). The complexity factor explained $11.99 \%$ of the total variation and was heavily loaded on the variables: Performance and outcome expectations (0.867), complexity of the innovation (0.855), relative disadvantage of the innovation (0.79) and lack of implementation requirement (0.696). The third factor, perceived risk explains $7.77 \%$ of the variance and is heavily loaded on the variables: Resistance to change $(0.958)$ and perceived difficulty in using the innovation $(0.958)$. The KMO was 0.908 which meant that EFA was appropriate and the Bartlett's Test of Sphericity shows that ris significantly different from $1(\mathrm{p}<0.05)$.

The EFA for the older adults identified also 3 factors, namely, lack of motivation, institutional provision, and perceived risk as the militating factors for innovation adoption with percentage explained variances 43.95, 13 and 10.25, respectively. The lack of motivation is heavily loaded on the variables: No business case for product $(0.797)$, lack of implementation requirement (0.786), relative disadvantage of the innovation (0.7), complexity of the innovation $(0.663)$, inadequate funding (0.649), performance and outcome expectations (0.614), and no time for innovation (time consuming) (0.543). The institutional provision factor is heavily loaded on the variables: Stiff legal requirements in using the innovation $(0.814)$, contracting issues between university and supplier (0.798), risk of affecting my cultural way of life (0.78), and no executive sponsorship (0.614). The perceived risk factor is heavily loaded on the variables: Resistance to change (0.925) and perceived difficulty in using the innovation (0.925). The KMO was 0.8 which meant that EFA was appropriate and the Bartlett's Test of Sphericity shows that $r$ is significantly different from $1(p<0.05)$. 


\section{Macrothink}

Journal of Management Research

ISSN 1941-899X

2016, Vol. 8, No. 4

Table 5. Exploratory Factor Analysis to Determine Factors that Act as Roadblock to Innovation

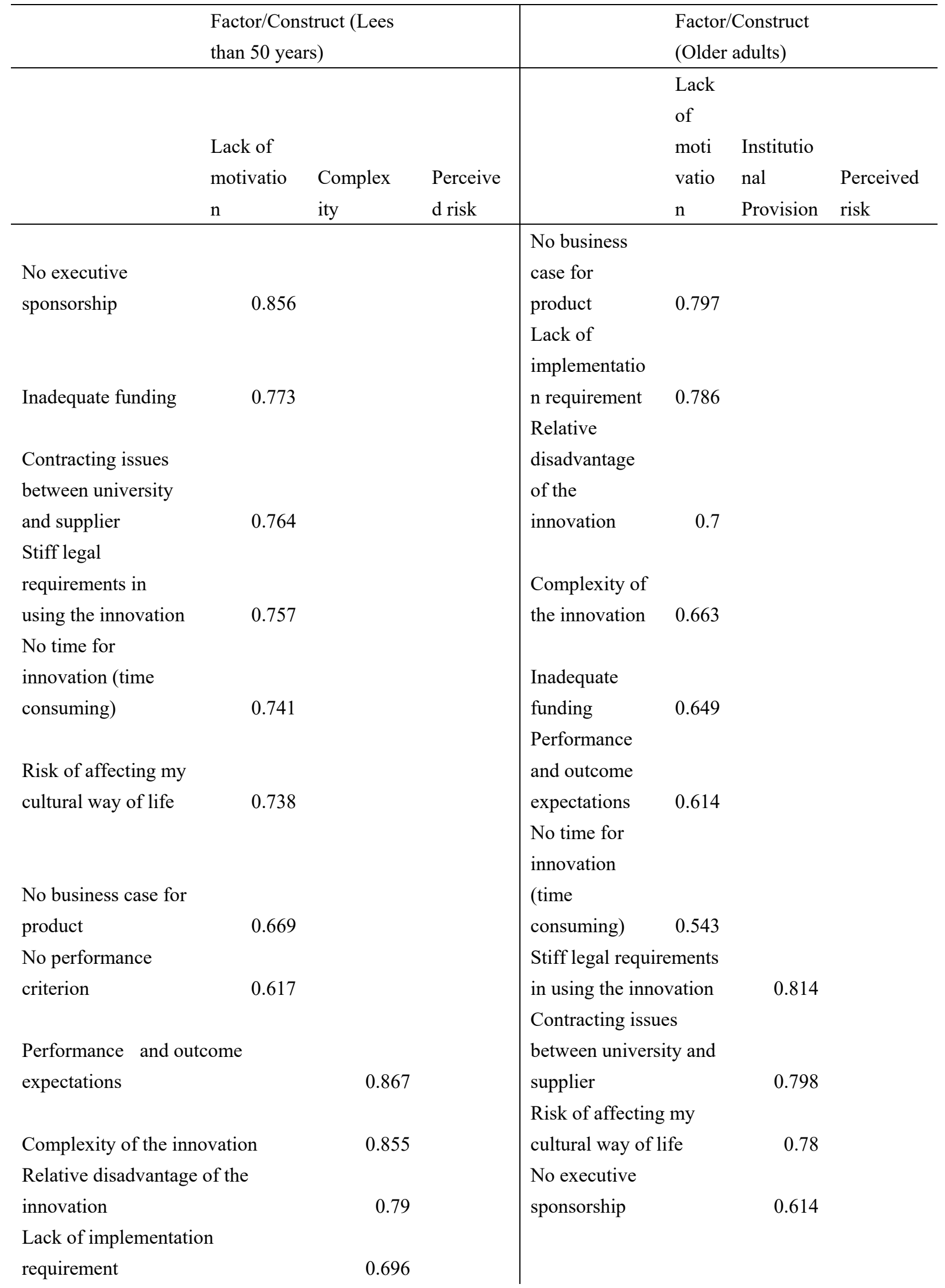




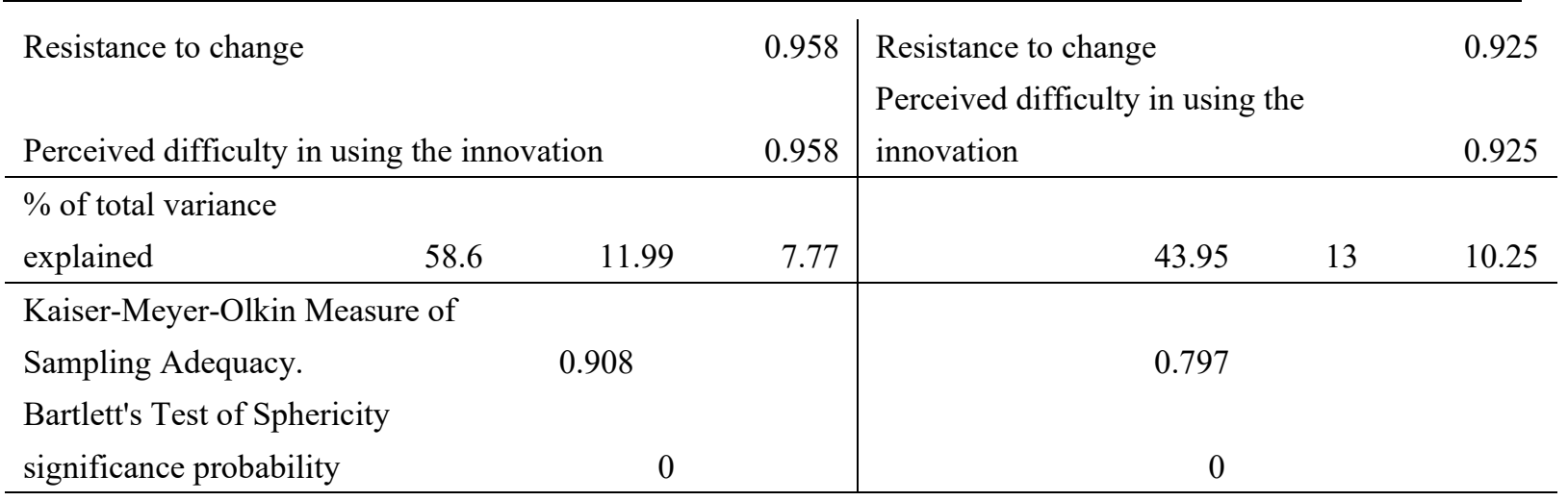

Extraction Method: Principal Component Analysis.

Rotation Method: Varimax with Kaiser Normalization.

\section{Factors that act as institutional barriers}

In order to explore the institutional barriers to innovation adoption among University of Botswana staff, the respondents were asked to rate some factors in terms of how they act as institutional barriers to implementing innovations using the scale: $1=$ Very unimportant; 2=Unimportant; $3=$ Neutral; 4=Important; $5=$ Very important. The responses were subjected to exploratory factor analysis (EFA) using the principal component analysis and Varimax with Kaiser Normalization procedure. The results of the EFA for respondents less than 50 years and those 50 years and over (older adults) are shown separately in Table 6.

The EFA identified only one factor for the respondents aged less than50 years, which is heavily loaded on all the variables with factor loadings ranging from 0.893 to 0.771 in decreasing order and two factors (innovation environment and lack of resources) for the older adults. The miscellaneous factor explained $68.1 \%$ of the variation in the variables and with $\mathrm{KMO} \alpha=0.911$ indicating excellent conditions for application of factor analysis. The Bartlett's Test of Sphericity was significant $(\mathrm{p}<0.05)$.

For the older adults, the innovation environment factor was heavily loaded on the variables, diversity of transportation (treat one another in ways that are fair, courteous and compassionate, recognizing everyone's contributions) (0.809), company has a risk-adverse environment (0.802), stovepipe organisational structure (the structure of the organization restricts flow of information through rigid lines of control) (0.794), conflicting objective (0.779), lack of political will to take on advantage (0.779), and people's resistance to change $(0.764)$. The factor explained $56.3 \%$ of the total variation in the variables. The lack of resources factor was heavily loaded on the variables, lack of facilities (0.856), unavailability of fund (0.838), and over sensitivity to public opinions (0.663). The factor explained $12.9 \%$ of the total variation in the variables. The KMO $\alpha=0.8$ indicating good conditions for application of factor analysis. The Bartlett's Test of Sphericity was significant $(\mathrm{p}<0.05)$. 
Table 6. Exploratory factor analysis of factors that act as institutional barriers to innovation adoption

\begin{tabular}{|c|c|c|c|c|}
\hline \multicolumn{2}{|l|}{ Less than 50 years } & \multirow[b]{3}{*}{ Variables } & \multirow{2}{*}{\multicolumn{2}{|c|}{$\begin{array}{c}50 \text { years or over (older } \\
\text { adults) }\end{array}$}} \\
\hline & Factor & & & \\
\hline Variables & Miscellaneous & & $\begin{array}{l}\text { Innovation } \\
\text { environment }\end{array}$ & $\begin{array}{r}\text { Lack of } \\
\text { resources }\end{array}$ \\
\hline Conflicting objective & 0.893 & $\begin{array}{l}\text { Diversity of transportation } \\
\text { (treat one another in ways that } \\
\text { are fair, courteous and } \\
\text { compassionate, recognizing } \\
\text { everyone's contributions). }\end{array}$ & 0.809 & \\
\hline $\begin{array}{l}\text { Diversity of transportation (treat } \\
\text { one another in ways that are fair, } \\
\text { courteous and compassionate, } \\
\text { recognizing everyone's } \\
\text { contributions). }\end{array}$ & 0.874 & $\begin{array}{l}\text { Company has a risk-adverse } \\
\text { environment }\end{array}$ & 0.802 & \\
\hline $\begin{array}{l}\text { Stovepipe organisational } \\
\text { structure (the structure of the } \\
\text { organization restricts flow of } \\
\text { information through rigid lines } \\
\text { of control) }\end{array}$ & 0.847 & $\begin{array}{l}\text { Stovepipe organisational } \\
\text { structure (the structure of the } \\
\text { organization restricts flow of } \\
\text { information through rigid lines } \\
\text { of control) }\end{array}$ & 0.794 & \\
\hline $\begin{array}{l}\text { Company has a risk-adverse } \\
\text { environment }\end{array}$ & 0.839 & Conflicting objective & 0.779 & \\
\hline $\begin{array}{l}\text { Over sensitivity to public } \\
\text { opinions }\end{array}$ & 0.825 & $\begin{array}{l}\text { Lack of political will to take on } \\
\text { advantage }\end{array}$ & 0.779 & \\
\hline $\begin{array}{l}\text { Lack of political will to take on } \\
\text { advantage }\end{array}$ & 0.808 & People's resistance to change & 0.764 & \\
\hline Unavailability of fund & 0.785 & Lack of facilities & & 0.856 \\
\hline Lack of facilities & 0.776 & Unavailability of fund & & 0.838 \\
\hline People's resistance to change & 0.771 & Over sensitivity to public opinions & & 0.663 \\
\hline \%age explained variance & 68.1 & & 56.3 & 12.9 \\
\hline $\begin{array}{l}\text { Kaiser-Meyer-Olkin Measure of } \\
\text { Sampling Adequacy. }\end{array}$ & 0.911 & & 0.8 & \\
\hline $\begin{array}{l}\text { Bartlett's Test of Sphericity } \\
\text { significance probability }\end{array}$ & 0 & & 0 & \\
\hline $\begin{array}{l}\text { Extraction Method: Principal Con } \\
\text { Rotation Method: Varimax with }\end{array}$ & $\begin{array}{l}\text { onent Analysis. } \\
\text { aiser Normaliza }\end{array}$ & & & \\
\hline
\end{tabular}

\section{Innovation implementation boosters}

The respondents were asked to rate a list of variables using a 5-point Likert scale, $1=$ Very unimportant; 2=Unimportant; 3=Neutral; 4=Important; 5=Very important, what can be done 
to improve how innovations are implemented at the university. The responses were subjected to EFA delineated by the age of respondents. Table 7 shows the extraction of the factors that explains the implementation boosters.

Only one factor was identified for the less than 50 year-old respondents with factor loadings ranging from 0.906 to 0.541 in decreasing order. The factor explained $65.6 \%$ of the variation in the variables and with KMO $\alpha=0.941$ indicating excellent/appropriate conditions for application of factor analysis. The Bartlett's Test of Sphericity was significant $(\mathrm{p}<0.05)$. Two factors, motivation and training, were extracted for the older adults. The motivation construct was heavily loaded on the variables, clear innovation objectives $(0.888)$, strong management support (0.88), adequate innovation funding (0.879), adequate deployment support (0.857), ensure that product matches needs $(0.834)$, refer to successful projects conducted using the innovation (0.777), customer/user participation ( 0.759$), \quad$ create incentives to innovate $(0.735)$, and demonstrated innovation benefits (0.714) with total explained variance of $69.2 \%$. The training construct was heavily loaded on the variables; ensure relative ease of use of innovation (0.804), specialized instructions concerning the innovation must be available (0.8), a specific person or group must always be available for assistance with system difficulties (0.76), guidance should be available to me in selection of the innovation (0.747), avail training on new technology $(0.731)$ and sensitivity to age diversity in the institution (0.608). The factor explained $8.3 \%$ of the total variation in the variables with $\mathrm{KMO} \alpha=0.897$ indicating excellent/appropriate conditions for application of factor analysis. The Bartlett's Test of Sphericity was significant $(\mathrm{p}<0.05$.

Table 7. Implementation boosters for innovation adoption

\begin{tabular}{|c|c|c|c|c|}
\hline \multicolumn{2}{|l|}{ Less than 50 years } & \multirow[b]{3}{*}{ Variables } & \multirow{2}{*}{\multicolumn{2}{|c|}{$\begin{array}{c}50 \text { years or over } \\
\text { Factors }\end{array}$}} \\
\hline \multirow[b]{2}{*}{ Variables } & \multirow{2}{*}{$\begin{array}{l}\text { Factor } \\
\text { General }\end{array}$} & & & \\
\hline & & & Motivation & Training \\
\hline Avail training on new technology & 0.906 & $\begin{array}{l}\text { Clear innovation } \\
\text { objectives }\end{array}$ & 0.888 & \\
\hline Customer/user participation & 0.89 & $\begin{array}{ll}\text { Strong management } \\
\text { support }\end{array}$ & 0.88 & \\
\hline Ensure relative ease of use of innovation & 0.869 & innovation & 0.879 & \\
\hline $\begin{array}{l}\text { A specific person or group must always } \\
\text { be available for assistance with system } \\
\text { difficulties }\end{array}$ & 0.866 & $\begin{array}{l}\text { Adequate deployment } \\
\text { support }\end{array}$ & 0.857 & \\
\hline Strong management support & 0.865 & $\begin{array}{l}\text { Ensure that product } \\
\text { matches needs }\end{array}$ & 0.834 & \\
\hline Ensure that product matches needs & 0.864 & $\begin{array}{l}\text { Refer to successful } \\
\text { projects conducted using } \\
\text { the innovation }\end{array}$ & 0.777 & \\
\hline Clear innovation objectives & 0.861 & $\begin{array}{l}\text { Customer/user } \\
\text { participation }\end{array}$ & 0.759 & \\
\hline
\end{tabular}




\begin{tabular}{|c|c|c|c|}
\hline $\begin{array}{l}\text { Specialized instructions concerning the } \\
\text { innovation must be available }\end{array}$ & 0.852 & $\begin{array}{l}\text { Create incentives to } \\
\text { innovate }\end{array}$ & \\
\hline Adequate deployment support & 0.819 & $\begin{array}{l}\text { Demonstrated innovation } \\
\text { benefits }\end{array}$ & \\
\hline $\begin{array}{l}\text { Guidance should be available to me in } \\
\text { selection of the innovation }\end{array}$ & 0.809 & Ensure relative ease of use of innovation & 0.804 \\
\hline Demonstrated innovation benefits & 0.796 & $\begin{array}{l}\text { Specialized instructions concerning the } \\
\text { innovation must be available }\end{array}$ & 0.800 \\
\hline Adequate innovation funding & 0.757 & $\begin{array}{l}\text { A specific person or group must always be } \\
\text { available for assistance with system } \\
\text { difficulties }\end{array}$ & 0.760 \\
\hline Create incentives to innovate & 0.69 & $\begin{array}{l}\text { Guidance should be available to me in } \\
\text { selection of the innovation }\end{array}$ & 0.747 \\
\hline $\begin{array}{l}\text { Refer to successful projects conducted } \\
\text { using the innovation }\end{array}$ & 0.673 & Avail training on new technology & 0.731 \\
\hline $\begin{array}{l}\text { Sensitivity to age diversity in the } \\
\text { institution }\end{array}$ & 0.541 & Sensitivity to age diversity in the institution & 0.608 \\
\hline \%age explained variance & 65.6 & 69.2 & 8.3 \\
\hline $\begin{array}{l}\text { Kaiser-Meyer-Olkin Measure of } \\
\text { Sampling Adequacy. }\end{array}$ & 0.941 & $\mathbf{0 . 8 9 7}$ & \\
\hline $\begin{array}{l}\text { Bartlett's Test of Sphericity significance } \\
\text { probability }\end{array}$ & $\mathbf{0}$ & $\mathbf{0}$ & \\
\hline
\end{tabular}

Extraction Method: Principal Component Analysis.

Rotation Method: Varimax with Kaiser Normalization.

\section{Training- an innovation use booster}

The results in Table7 point to training on the new innovation (technology) as booster to innovation use. The respondents were asked to indicate what could be done to enhance the usability of the training to foster the adoption of the available innovation technology. The responses are summarized in Figure 5. An overwhelming percentage (95\%) of the respondents indicated that the trainers should take into consideration the levels of computer expertise of the trainees when designing the training programmes; the trainers should follow-up the trainees $(85 \%)$, and that the number of hours/periods for the training should be increased $(76 \%)$. 


\section{Macrothink}

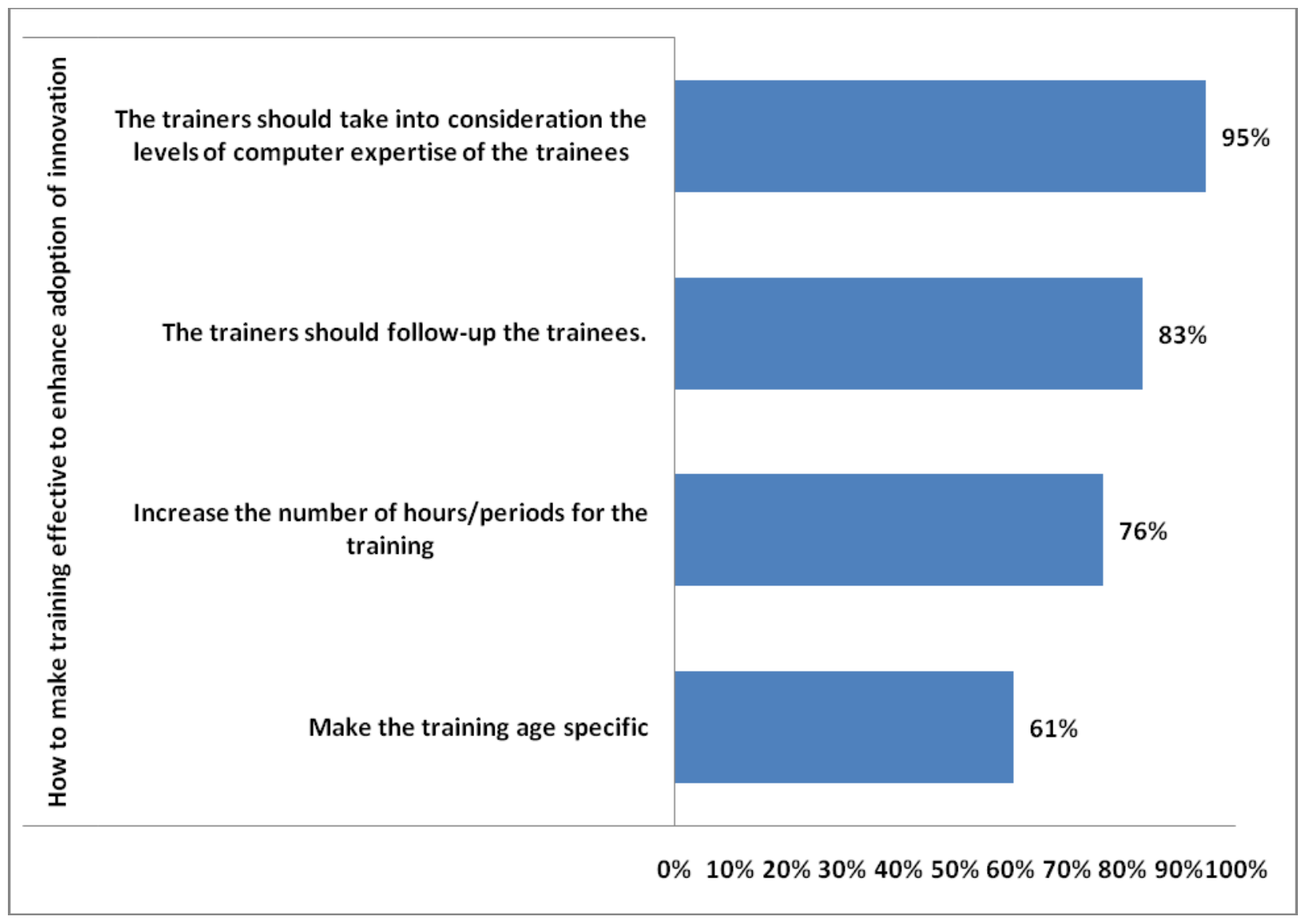

Figure 5. Enhancing effective innovation use through training

\section{Discussion of results}

The study set as its objectives to explore the level of resistance to innovation by the older adults of the University of Botswana and in addition, to identify factors that act as roadblocks, institutional barriers and boosters to innovation adoption. A comparison of the older adults' attitudes to innovation resistance with those less than 50 years was also carried out.

The results of the study show that older adults (50 years and over) in the university are more resistant (early majority (36.1\%), late majority (16.9\%) and laggards $(1.2 \%)$ ) to innovation than the younger people, less than 50 years old. This result agrees with previous studies (Mattila et al. 2003; Laukkanen et al. 2007;Oppenauer, 2009) which have shown that mature customers are late adopters of new electronic services. Rose and Fogarty (2010) reported that the innovators are highly motivated and confident in their ability to make technology work. They are younger, generally male, have a higher income, and are better educated than late adopters. However, the older adults in our study are more educated and have higher monthly income than the younger respondents in the study (Table 1).

Access to computer at home/office and years of internet experience have been shown in this study to be positive significant predictors of the use of innovation technology $(p<0.05)$ while education, monthly income and age are not significant predictors of usage. However, the access to computer at home/office and years of internet experience have not translated 
into higher usage of the available technologies since the older adults as well the younger ones are only comfortable with use of some of the innovations. This result agrees with Rose and Fogarty (2010) who noted that while mature consumers have adopted the use of computers and the internet, this same level of adoption does not flow through to internet banking. The authors found out that the higher level of discomfort and in particular insecurity, play a stronger inhibiting role when it comes to adopting internet banking across the segments.

The study shows that high monthly income is negatively correlated with innovation use. For instance, the respondents who earned P28,000.00 and over were found to be less likely to use innovation than those who earned below P13, 000.00. This result agrees with an earlier finding by Luarn and Lin (2005), which showed that financial cost considerations have a negative effect on the intention to use mobile banking. Thus, the higher the cost of an innovation, the higher is the perceived economic risk. It is, therefore, not how much money one has that determine usage of innovation but other factors, such as the consumer characteristics, the value the individual attaches to the innovation which is closely related to its perceived usefulness and relative advantage of using the innovation, and the innovation characteristics ( Khan and Hyunwoo, 2009; Rogers, 2003; Ram and Sheth, 1989).Ram and Sheth (1989) proposed that the usage barrier comes into operation when an innovation is not well-suited with existing workflows, practices or habits (Laukkanen et al., 2007). It has been shown that the mature consumers (the older adults) have more purchasing power than many other groups of consumers, and according to Moschis (2003), they invest more, spend more on luxury products but, however, choose their products on the basis of quality and brand name.

Two factors, lack of motivation and perceived risk of using the innovation, are twocommon factors that act as roadblocks to innovation adoption by respondents less than 50 years old as well as those 50 years and above (older adults). However, complexity of the innovation was also identified as an impeding factor to the respondents less than 50 years. On the other hand, innovation environment and lack of resources acted as barriers to the older adults in using the innovation while motivation and training were identified as boosters of the innovation use for the older adults. When the older adults, who did not use the innovation, were asked 'Why they did not use them?', the three main reasons given were: Using the innovation takes too much time from normal duties (71.4\%) (Relative disadvantage and Lack of motivation); working with the innovation is so complicated, it is difficult to understand what is going on $(71.4 \%)$ (Complexity of the innovation); using the innovation involves too much time doing mechanical as well as programming operations for data input (78.6\%) (Relative difficulty working with the innovation) and it takes too long to learn how to use the innovation to make it worth the effort $(78.6 \%)$ (Perceived risks, Innovation environment not conducive). These results are supported by several findings from previous works. For instance, it has been shown that motivation drives consumers' needs and intentions to adopt innovation (Lee Matthew et al., 2007). Acceptance of innovation is motivated by the perceived usefulness and perceived enjoyments derived in using the innovation. Therefore, if users perceive some technology to be useful and easy to use, it is more likely that they will use it. It has also been found by Devis et al., (1992) that consumers' perceived usefulness increases through increase in perceived ease of use. 
The level of complexity of innovation was identified by respondents less than 50 years in age as roadblock to innovation use. Rogers and Shoemaker (1971, p. 154) defined complexity as "the degree to which the innovation is perceived as relatively difficult to understand, use or comprehend". The complexity factor is heavily loaded on performance and outcome expectations and perceived difficulty in using the innovation and complexity of the innovation. Complexity has been shown to be negatively related to the innovation diffusion and positively related to innovation resistance (Dunphy \& Herbig, 1995, Tornatzky \& Klein, 1982). One is in no doubt, therefore, why a substantial percentage $(85.5 \%)$ of the older adults' participants has been classified as late adopters of innovation. Innovative products that are considerably complex require lot of skills, efforts and training to adopt and use (Tan and Teo, 2000; Khan and Hyunwoo, 2009). The lack of motivation factor is heavily loaded on the variables: No business case for product, lack of implementation requirement and relative disadvantage of the innovation. In this context, one could examine the constant requirement of the different innovations for a change password. In some of the innovative products e.g, ASAS, the user is required to go through rigorous programmes to attain some outcomes. The user loses track of theperceived usefulness and perceived enjoyment in technology adoption (Lee Matthew et al., 2007) and become resistant to the technology. Davis et al. (1992) argue that perceived usefulness (PU) and perceived ease of use (PEOU) are the two ingredients of extrinsic motivation, and the authors found out that when users perceive something (technology) to be useful and easy to use, it is more probable that they will use it.

The perceived risks as factor constituting a roadblock in using innovation are associated with physical, social or economic consequences, performance uncertainty and perceived side effect inherent in the innovation (Sheth, 1981). The fact that this factor is heavily loaded on resistance to change and perceived difficulty in using the innovation agrees with previous studies and observations. Kuisma et al. (2007) found that some of the non-users of internet banking consider it to be difficult, inconvenient and slow to use. Moreover, they report that some of the non-users feel that the proceeding at the computer monitor is unclear and the use of changing PIN codes is inconvenient as the codes need to be carried along.

As a way of boosting staff use of the innovations in the university, the older adults' participants identified motivation and training as important factors. In order to motivate the staff to use the innovation, the older adults recommended that there should be clear innovation objectives, strong management support, adequate innovation funding, adequate deployment support and the providers should ensure that products match the needs of staff members. They also recommended for training to ensure relative ease of use of innovation, specialized instructions concerning the innovation must be available and that a specific person or group must always be available for assistance with system difficulties. These results are in agreement with several previous findings. For instance, Bauernschuster et al. (2008) in their paper on the Impact of Continuous Training on a Firm's Innovations, found out, using simple percentages as well as a simple multivariate regression framework, that continuous training of employees positively influences innovation activity and innovative activity. The Pew Internet and American Life Project showed thatlesser use of computer and Internet is related to higher age, lower education and socioeconomic status, minorities and 
people with disabilities (Pew Internet and American Life Project, 2007). Broadyet al. (2008) conclude, however, that similarities are more prevalent than differences in computer use between younger and older adults. The authors hypothesize that older people would perform as well as younger persons if they receive adequate training and given enough time to master new skills. In another study (Charness et al., 2001), computer performance differences were shown to be absent if the level of computer experience was similar within the age group. Thus, the level of experience and training of new skills seems to have more influence on computer performance than age and age related attitudes.

\section{Conclusion}

In the light of the findings from this study, the authors conclude that since the older adults constitute a substantial proportion of the staff of the university, they should be sufficiently motivated to use the available innovation through trainings that are age-specific and that existing skills of the older adults should be put into consideration when designing these programmes. Such training will motivate the older adults and reduce the perceived risks and complexity in the usage of the innovations.

\section{References}

Bauernschuster,S., Falck, O., \& Heblich, S. (2008). The Impact of Continuous Training on a Firm's Innovations .Cesifo Working Paper No. 2258 Category 9: Industrial Organisation March 2008

Bradley, L., \& Stewart, K. (2002). A Delphi study of the drivers and inhibitors of Internet banking.International. Journal of Bank Marketing, 20(6), 250-260. http://dx.doi.org/10.1108/02652320210446715

Broady T., Chan, A., \& Caputi, P. (2008).Comparison of older and younger adults' attitudes towards and abilities with computers: implications for training and learning. British Journal of Educational Technology, 2008 early view.

Charness, N., Kelly, CL., Bosman, E., \& Mottram, M. (2001).Word processing training and retraining: effects of adult age, experience, and interface. Psychology of Aging, 16(1), 110-127. http://dx.doi.org/10.1037/0882-7974.16.1.110

Connor, O., \& Colarelli,G.(1998). Market learning and radical innovation: A cross case comparison of eight radical innovation products. The Journal of Product innovation management, 15, 151-166. http://dx.doi.org/10.1111/1540-5885.1520151

Davis, F.D.,Bagozzi, R.P., \& Warshaw, P.R. (1992).Extrinsic and intrinsic motivation to use computers in the workplace. Journal of Applied Social Psychology, 22(14), 1111-1132. http://dx.doi.org/10.1111/j.1559-1816.1992.tb00945.x

Dunphy, S., \& Herbig, P.A. (1995). Acceptance of innovations: The customer is the key! The Journal of High Technology Management Research, 6, 193-209. http://dx.doi.org/10.1016/1047-8310(95)90014-4 
George, D., \& Mallery, P. (2003). SPSS for Windows step by step: A simple guide and reference. 11.0 update (4th ed.). Boston: Allyn\& Bacon p. 231

Härkönen, A. (2004). Service Innovation Resistance among Mature Consumers. The 2004 European Marketing Academy Conference, 18-21 May in Murcia, Spain.

Hosseini, M. H.,Delaviz, M., Derakhshide, H., \& Delaviz, M. (2016). Factors Affecting Consumer Resistance to Innovation in Mobile Phone Industry. International Journal of Asian Social Science, 6(9), 497-509. http://dx.doi.org/10.18488/journal.1/2016.6.9/1.9.497.509

Khan, K., \& Hyunwoo K. (2009). Factors Affecting Consumer Resistance to Innovation -A study of Smartphones. Jönköping International Business School, Sweden May, 2009

Kwon, W.S., \& Noh, M. (2010). The influence of prior experience and age on mature consumers' perceptions and intentions of internet apparel shopping. Journal of Fashion Marketing and Management, 14(3), 335-349. http://dx.doi.org/10.1108/13612021011061825

Kuisma, T., Laukkanen,T., \& Hiltunen, M. (2007). Mapping the reasons for resistance to internet banking: A means-end approach. International Journal of Information Management, 27(11), 75-75. http://dx.doi.org/10.1016/j.ijinfomgt.2006.08.006

Laukkanen, P., Sinkkonen, S., \& Laukkanen, T. (2008). Consumer resistance to Internet banking: Postponers, opponents and rejecters. The International Journal of Bank Marketing, 26(6), 440-455. http://dx.doi.org/10.1108/02652320810902451

Laukkanen, T., Sinkkonen, S., Kivijärvi , M., and Laukkanen, P. (2007). Innovation resistance among mature consumers. Journal of Consumer Marketing, 24(7), 419-427. http://dx.doi.org/10.1108/07363760710834834

Lee M.K. O., Cheung,C. M. K. \& Chen, Z. (2007) . Understanding user acceptance of multimedia messaging services: An empirical study. Journal of the American Society for Information Science and Technology, 58, 2066-2066. http://dx.doi.org/10.1002/asi.20670

Lian, J., \& Yen, D. C. (2014). Online shopping drivers and barriers for older adults: Age and gender Differences. Computers in Human Behavior, 37, 133-143.

Lundsford,D., \& Burnett, M. (1992). Marketing Product Innovations to the Elderly: Understanding the Barriers to Adoption. The Journal of Consumer Marketing, 9(4).

Mattila,M., Karjaluoto, H., \& Pento, T. (2003). Internet banking adoption among mature customers: Early majority or laggard? The Journal of Services Marketing, 17(5), 514-528 http://dx.doi.org/10.1108/08876040310486294

McCloskey, D. W. (2006). The importance of ease of use, usefulness, and trust to online consumers: An examination of the technology acceptance model with older customers. Journal of Organizational and End User Computing, 18(3), 47-65. http://dx.doi.org/10.4018/joeuc.2006070103

Mirella, K., Nick,L., and Wetzels, M. (2009). An exploration of consumer resistance to innovation and its antecedents. Journal of Economic Psychology, 11(6), 47-61 
Molesworth, M., \& Suortti, J. P. (2002). Buying cars online: The adoption of the Web for high-involvement, high-cost Purchases. Journal of Consumer Behaviour, 2(2), 155-168 http://dx.doi.org/10.1002/cb.97

Orcutt, L.H., \& ALKadri, M.Y. (2009). Barriers and Enablers of Innovation: A Pilot Survey of Transportation Professionals. A TRB manuscript submitted for peer review and for the 2009 Compendium of papers and possible publications in the Transportation Research Record.

Oppenauer, C. (2009). Motivation and needs for technology use in old age. Gerontechnology, 8(2), 82-87. http://dx.doi.org/10.4017/gt.2009.08.02.006.00

Pew Internet and American Life Project. (2016). A typology of information and communication

users.http://www.pewinternet.org/Reports/2007/A-Typology-of-Informationand-Communicat ion-Technology-Users. aspx; accessed May 20, 2016

Pfeil, U., Arjan, R., \& Zaphiris, P. (2009). Age Differences in online social networking - A study of user profiles and the social capital divide among teenagers and old users in MySpace. Computers in Human Behavior, 25(3), 643-654. http://dx.doi.org/10.1016/j.chb.2008.08.015

Ram, S. (1987). Amodel of Innovation Resistance, in NA-Advances in consumer Research, 14, eds. Melanie Wallendorf and Paul Anderson, Provo, UT: Association for Research, Pages: 208-212.

Ram, S. (1989). Successful innovation using strategies to reduce consumer resistance- An empirical test. The Journal of Product Innovation Management, 6, 20-34. http://dx.doi.org/10.1016/0737-6782(89)90011-8

Ram, S., \& Sheth, N.J. (1989). Consumer resistance to innovation: The marketing problem and its solution. The Journal of Consumer Marketing, 6(2), 5-14. http://dx.doi.org/10.1108/EUM0000000002542

Ram, S. (1985).Marketing Strategies to Overcome Innovation Resistance: A Laboratory Experiment. Unpublished Doctoral Dissertation, University of Illinois at Urbana Champaign, 1985.

Reisenwitz, T., Iyer, R., Kuhlmeier, D.B., an Eastman, J.K. (2007). The elderly's Internet usage: An updated look. Journal of Consumer Marketing, 24(7), 406-418. http://dx.doi.org/10.1108/07363760710834825

Rogers, E. (2003). Diffusion of Innovations, 5th edition, Free Press, New York.

Rose, J., \& Fogarty, G. (2010).Technology Readiness and Segmentation Profile of Mature Consumers. Academy of World Business, Marketing \& Management Development, 4(1). July 2010 Conference Proceedings. James Cook University, Australia. 
Ryu, M. H., Kim, S., \& Lee, E. (2009).Understanding the factors affecting online elderly user's participation in video UCC services. Computers in Human Behavior, 25(3), 619-632. http://dx.doi.org/10.1016/j.chb.2008.08.013

Sevick, M.A., and Bradham, D.D. (1997). Economic value of caregiver effort in maintaining long-term ventilator-assisted individuals at home. Heart Lung. Mar-Ap., 26(2), 148-57. http://dx.doi.org/10.1016/s0147-9563(97)90075-3

Sheth, J.N. (1981). Psychology of innovation resistance: The Less Developed Concept (LDC) in Diffusion Research in Research in marketing ed. J.N. Sheth..4. Jai Press Inc., 273-282.

The Creative Research Systems. (2012). Sample size calculator.Available at http://www.surveysystem.com/sscalc.htm. Accessed 08 May 2012

Thomas, R. (1971). Innovative Behaviour and Communication. New York: Holt, Rinehart and Winston.

Tornatzky, L., \& Klein, K. (1982). Innovation Characteristics and Innovation Adoption Implementation: A Meta-Analysis of Findings. IEEE Transactions on Engineering Management, 29(1), 28-43. http://dx.doi.org/10.1109/TEM.1982.6447463

Visser, P.S., Krosnick, J.A., Marquette, J., \& Curtin, M. (1996). Mail Surveys for Election Forecasting?An Evaluation of the Columbus Dispatch Poll. Public Opinion Quarterly, 60(2), 181-227. http://dx.doi.org/10.1086/297748 